\title{
About Group Psychology and Team-building Theory Application in College Student Association Management
}

\author{
Hong-Mei Wang ${ }^{1, a}$, Hong-Ying Deng ${ }^{2, b,{ }^{*}}$ \\ ${ }^{1}$ Civil Aviation Flight University of China, Sichuan, Guanghan \\ awanghongmeicn@163.com, b872468454@qq.com \\ ${ }^{*}$ Corresponding author
}

Keywords: Management psychology, Student association, Management team building theory.

\begin{abstract}
Community college students as "second class" students taught in an important position and growth is to develop teamwork students, improve the overall quality of an important carrier of the students. But for community college students practical management process because there are many objective factors to make this function to student organizations are not well represented, how to use the basic theory and methods to improve the management efficiency of management psychology and achieve management objectives, and Employment and Quality Development for Students play an active role to be worth every educator thinking and practice areas.

Modern mass production to specialization, collaborative direction, enterprises and institutions in the 21 st century are faced with the important task of building a team, casting teamwork. Therefore, the contemporary college graduates put new demands to university graduates into the community at the time not only to have a solid professional skill, but also with a sense of teamwork, understanding and the ability to integrate into the team. But due to its own mass, autonomy, openness and other factors affecting community college students, the content and direction of development of specific activities likely to deviations in the actual development process. Therefore, community college students how to conduct proper guidance and management is particularly important. Psychology management team on the basic theory and team building has far-reaching implications for community college students create a new situation management.
\end{abstract}

\section{Introduction of team and team building theory}

Generally speaking, the team is defined by two or more members, they share a common behavioral goals, and maintain working relationships of mutual responsibility, shared a common outcome - a way to achieve the common goal of mutual cooperation of individuals by formal groups. The team's goals are not members of the exchanges and cooperation can not be completed. After the formation of the team, its members must quickly develop a suitable mix of capabilities to accomplish team goals.

Team building is a process, in this process, participants and facilitators will enhance mutual trust, relatively honest, willing to explore the impact of the working group played well the role of the core issues and the creation of an unusual performance.

Community college students possess all kinds of such features, student organizations from different professional grade classmates, because they had the same interests to become a community, they are a team of four basic types (functional teams, problem-solving teams, cross team and self-management) in typical self-managed teams. With respect to the university for student societies traditional management methods, the use of teams and team building theory in the management of community college students are more in line with student organizations "self-education, self-serving, self-management" approach, can effectively promote the internal construction of student societies and institutional development, and constantly enhance community cohesion, but also to continue to improve the effectiveness of management and student organizations, while promoting students' quality development and teamwork to be established so that the overall objective of the student community management can be achieved. 


\section{Team and the importance of team-building theory in the management of community college students}

The main problem for the management of community college students currently exist in the actual process of application management team and team-building theory to guide the construction of student organizations has a strong practical significance:

\section{Community management methods are simple, hinder the development of societies}

In reality all the large number of community college students, community types, the school administration for its management stays at the macro-level guidance, management processes focus on the approval of activities, contact the venue to collect basic work activity report them. It is similar to management due to the offset center of gravity led to the development of student societies always in a relatively low level, from the perspective of the theory of team building look is always in the formation of student organizations and shock stage team members of student organizations can not participate get more training opportunities in the community, which appeared smug when freshman join associations, community activities disheartened sophomore, junior and gone and community development Dahushangdang vicious cycle.

\section{Single community activities, hinder college students to shape and develop teamwork}

At present, although many types of societies, but similar activity patterns, activities are more single, usually lectures, seminars and other organizations, lack of new ideas and influence. Teamwork shaping community members need to be able to make a strong sense of belonging and a sense of community one brand activities, the need to carry out the activities can be provided to members of the challenging work. Single community activities obviously can not meet the basic psychological needs of community members and the community to join the initial desire can not form the coexistence of consciousness and deep feelings between old members and the community. Based on this, our students reach teamwork concept in the community, the more feel than the collaboration of team members are able to bring a sense of security and cohesion, teamwork and can not and will not agree to work when they leave school partners harmony, good communication potential problems.

\section{Forging team leadership style of the student community leaders work a vacuum zone}

Why set up the problem of community college students in our country now have a more clear answer, the student community colleges and universities to achieve educational reform is an important carrier of contemporary ideological and political education of college students and expand the quality of training of the main front. But in reality, the process of building a community association management departments on how to establish their own communities to help students to establish the direction of development, to create and participate in their own community for accurate positioning of these educators is that we have to face the problem. Most of the core members of student organizations to ignore the traditional inherited and convergence of old and new members, just pay attention to their achievements during his tenure activities, without concern for the overall community development goals and plans, resulting in community activities fits and starts, the lack of stability and durability . This is our team leadership style forged in the management process is not enough awareness of community leaders and even missing embodies.

In the sense of management psychology, the university student organizations that exist in the management of community-building aspects embodied in due to insufficient scientific methods in the management and rational led to the existence and operation of student organizations can not meet the psychological community members needs, student organizations can not achieve this should have training teamwork features, but also led to the emergence of bottlenecks in the development community. In such a social and practical background, the team and the team-building theory applied to college students in community management and construction is imminent, and it is one that we continue to explore effective ways to promote the management of community college students. 


\section{Team and team-building theory concrete application in the management of community college students}

\section{School level casting team}

The vast majority of colleges and universities will be set up on the basis of a number of student organizations on community organizations such as the Federation of the overall activities of student organizations to manage, how to find the complementarity between the various types of associations, societies and communities through collaboration between each other within Associations casting team, and then at each individual school level to help communities overcome the phenomenon of a single community activities, and on the basis of the principles established by community college students in the high order bits of the team to advance the interests of priority community college students management optimization system.

\section{Student Association injection level team}

Student organizations in the effective injection teamwork, community members can make full of energy and enthusiasm to participate in community self-management, mutual respect and mutual cooperation everyone can feel the process to bring in the community, and mutual tolerance, feel highly consistent development and improvement of the quality of their community, in their daily activities in the community and its members will be combined into a highly robust community of destiny, is achieved in a subtle sense of community college students education and training goals.

\section{Using the team and team-building theory to achieve the management of benign interaction with the management of}

Team and team building theory requires us to create a balance in the management process of personal and team, teamwork and personal development of mutually management atmosphere, the team set up by the goals and aspirations of common values, the use of the means to implement a series of education is socially acceptable norms of ethical behavior, and melt into the ideas of college students, and guide them to produce teamwork behavior, teamwork training, establish a good manager in the management process and interaction is the manager, will have a beneficial management practices improve and enhance management efficiency.

In short, the management of the theoretical system of community college students we need to continue to explore, to practice, only the new theories and methods and the actual management process combining theoretical specific, constantly sum up the problems in the management process and the accumulation of experience in order to make our community college students manage more targeted and effective.

\section{Acknowledgement}

This research was financially supported by the J2014-95 On the project.

\section{References}

[1] The Soviet Union and Water Management Psychology (4th Edition) Shanghai: Fudan University Press.

[2] Yu Zhao Management Psychology (2nd Edition) Dalian: Dongbei University of Finance and Economics Press.

[3] Zhangxin Hao Modern Management Psychology [M] Beijing: China Renmin University Press. 